\title{
IL10RA wt Allele
}

National Cancer Institute

\section{Source}

National Cancer Institute. IL10RA wt Allele. NCI Thesaurus. Code C107584.

Human IL10RA wild-type allele is located in the vicinity of $11 \mathrm{q} 23.3$ and is approximately 15 $\mathrm{kb}$ in length. This allele, which encodes interleukin-10 receptor subunit alpha protein, is involved in the regulation of immunosuppression. Mutations in this gene are associated with inflammatory bowel disease 28, early onset, autosomal recessive. 